Research paper

\title{
Structural properties and transformations of precipitated FeS
}

\author{
Dorottya Csákberényi-Malasics a , Juan Diego Rodriguez-Blanco ${ }^{\mathrm{b}}$, Viktória Kovács Kis ${ }^{\mathrm{c}}$, Aleksander Rečnik ${ }^{\mathrm{d}}$, \\ Liane G. Benning ${ }^{\text {b }}$, Mihály Pósfai a,* \\ a Department of Earth and Environmental Sciences, University of Pannonia, Veszprém, POB 158, H8200, Hungary \\ ${ }^{\mathrm{b}}$ Earth and Biosphere Institute, School of Earth and Environment, University of Leeds, Leeds, LS2 9JT, UK \\ ${ }^{c}$ Research Institute for Technical Physics and Materials Science, Budapest, POB 49, H-1525, Hungary \\ ${ }^{d}$ Nanostructured Materials Department, Jožef Stefan Institute, Jamova cesta 39, SI-1000 Ljubljana, Slovenia
}

\section{A R T I C L E I N F O}

\section{Article history:}

Received 21 July 2011

Received in revised form 12 December 2011

Accepted 13 December 2011

Available online 23 December 2011

Editor: J. Fein

\section{Keywords:}

Amorphous iron sulfide

Mackinawite

Greigite

Phase transformations

XRD

TEM

\section{A B S T R A C T}

Nanocrystalline iron sulfides form in diverse anoxic environments. The initial precipitate is commonly referred to as nanocrystalline mackinawite (FeS) or amorphous FeS. In order to better understand the structure of the initial precipitate and its conversion to mackinawite and greigite $\left(\mathrm{Fe}_{3} \mathrm{~S}_{4}\right)$, we studied synthetic iron sulfide samples that were precipitated from hydrous solutions near room temperature. The transformation of precipitated FeS was followed in both aqueous and dry aging experiments using X-ray powder diffraction (XRD) and scanning and transmission electron microscopy (SEM/TEM) and selected-area electron diffraction (SAED).

Under tightly controlled anoxic conditions the first precipitate was nanocrystalline mackinawite. In contrast, when anaerobic conditions during synthesis were not completely ensured, freshly precipitated iron sulfide was typically X-ray amorphous $\left(\mathrm{FeS}_{\mathrm{am}}\right)$, and showed only one broad Bragg-peak at $2 \Theta=16.5^{\circ}$ (5.4 $\left.\mathrm{A}\right)$. A distribution of interatomic distances calculated from pair-distribution function analysis of SAED patterns of $\mathrm{FeS}_{\mathrm{am}}$ showed that only short-range $(<7 \AA$ ) order was present in the bulk of the material, with Fe mainly present in tetrahedral coordination. SEM and TEM images confirmed the poorly ordered structure and showed that $\mathrm{FeS}_{\mathrm{am}}$ formed aggregates of curved, amorphous sheets that contained 3-8 structurally ordered layers at their cores. Such layers are generally assumed to be structurally similar to the tetrahedral iron sulfide layers in mackinawite. However, both inter- and intralayer spacings measured in high-resolution TEM images ( $\sim 3$ to 6.3 and $\sim 3.0$ to $3.1 \AA$, respectively) were significantly larger than the corresponding spacings in crystalline mackinawite (5.03 and $2.6 \AA$, respectively), suggesting that short-range structural order within the semi-ordered layers of $\mathrm{FeS}_{\mathrm{am}}$ was not mackinawite-like.

In aqueous aging experiments at room temperature, $\mathrm{FeS}_{\mathrm{am}}$ transformed into a mixture of mackinawite and greigite in $\sim 2$ months, and completely converted to platy greigite crystals after $\sim 10$ months. These aqueous transformations were likely driven by excess sulfur in the reacting solutions. We also studied the conversions of nanocrystalline mackinawite. In order to accelerate phase transitions, the initial FeS precipitate was heated to $120{ }^{\circ} \mathrm{C}$, resulting in the formation of crystalline mackinawite within $2 \mathrm{~h}$; at $150{ }^{\circ} \mathrm{C}$, the material converted directly to pyrrhotite. Finally, when stored in a dry state at room temperature, crystalline mackinawite converted to greigite in 3 months, much faster than in the equivalent experiments in the aqueous solution, probably as a result of a more oxidative environment.

The distinction between $\mathrm{FeS}_{\mathrm{am}}$ and nanocrystalline mackinawite is significant, since conditions for the formation of both phases are present in natural settings. Our experiments in a well-sealed anaerobic chamber simulate iron sulfide formation under anoxic conditions, whereas the samples that were prepared under less tightly controlled conditions can be regarded as representative of the oxic-anoxic transition zone in sediments. Our observations of the structural and morphological features of precipitated FeS ${ }_{\mathrm{am}}$ and the details of its aqueous conversion to greigite at ambient conditions are relevant to problems related to the biogeochemical cycling of elements in anoxic and suboxic marine sediments. An additional important finding is that even at moderately high temperatures (up to $170{ }^{\circ} \mathrm{C}$ ), the conversions of iron monosulfides follow different pathways than at ambient conditions.

(c) 2011 Elsevier B.V. All rights reserved.

\footnotetext{
* Corresponding author. Tel.: + 36 88624155; fax: + 3688624631. E-mail address: mihaly.posfai@gmail.com (M. Pósfai).
}

\section{Introduction}

Iron sulfides form in anoxic sediments as a result of the metabolic activity of sulfate-reducing bacteria (Berner, 1967). The first solid 
Table 1

Compositions, structural parameters and other characteristics of the iron sulfide phases discussed in this study.

\begin{tabular}{|c|c|c|c|c|c|c|}
\hline & & $\mathrm{FeS}_{\mathrm{am}}$ & Mackinawite & Greigite & Pyrrhotite & Troilite \\
\hline $\begin{array}{l}\text { Nominal } \\
\text { composition }\end{array}$ & & $\mathrm{FeS}$ & $\mathrm{FeS}$ & $\mathrm{Fe}_{3} \mathrm{~S}_{4}$ & $\mathrm{Fe}_{1-\mathrm{x}} \mathrm{S}$ & $\mathrm{FeS}$ \\
\hline Space group & & - & $\mathrm{P} 4 / \mathrm{nmm}$ & $\mathrm{Fd} 3 \mathrm{~m}$ & $\mathrm{P} 6 / \mathrm{mmc}$ or $\mathrm{F} 2 / \mathrm{d}$ & $\mathrm{P}_{3} / \mathrm{mmc}$ \\
\hline & $\mathrm{a}$ & - & $3.674 \AA$ & $9.876 \AA$ & $6.897^{\mathrm{a}}$ & $5.965 \AA$ \\
\hline \multirow[t]{2}{*}{ parameter } & $\mathrm{b}$ & - & & & $11.954^{\mathrm{a}}$ & \\
\hline & c & $5.2-5.5 \AA$ & $5.033 \AA$ & & $34.521^{\mathrm{a}}$ & $11.757 \AA$ \\
\hline $\begin{array}{l}\mathrm{Fe} \\
\text { coordination }\end{array}$ & & $?$ & Tetrahedral & $\begin{array}{l}\text { Tetrahedral and } \\
\text { octahedral }(8: 16)\end{array}$ & Octahedral & Octahedral \\
\hline Formation & & $\begin{array}{l}\text { First solid product from the } \\
\text { reaction of Fe (II) and sulfide ions. } \\
\text { Typically produces a single broad } \\
\text { peak in XRD patterns. } \\
\text { This study }\end{array}$ & $\begin{array}{l}\text { A major constituent of } \\
\text { FeS precipitated from } \\
\text { solutions, presumably } \\
\text { converts from } \mathrm{FeS}_{\text {fresh. }} \\
\text { Lennie et al. } 1995\end{array}$ & $\begin{array}{l}\mathrm{Fe}^{\mathrm{II}} \mathrm{Fe}^{\mathrm{III}} \text { sulfide, the } \\
\text { thiospinel of iron. It forms } \\
\text { from mackinawite and } \\
\text { can convert to pyrite. } \\
\text { Skinner et al. } 1964\end{array}$ & $\begin{array}{l}\text { Nonstoichiometric with } \mathrm{x} \text { ranging from } \\
0 \text { to } 0.125 \text {, includes monoclinic and } \\
\text { hexagonal variants. Primarily occurs in } \\
\text { igneous and metamorphic rocks. } \\
\text { De Villiers and Liles, } 2010\end{array}$ & $\begin{array}{l}\text { Stoichiometric, } \\
\text { hexagonal FeS, } \\
\text { forms in meteorites } \\
\text { and igneous rocks. } \\
\text { Skála et al. } 2006\end{array}$ \\
\hline Reference & & This study & Lennie et al., 1995 & Skinner et al., 1964 & De Villiers and Liles, 2010 & Skála et al., 2006 \\
\hline
\end{tabular}

${ }^{\text {a }}$ Cell parameters for $6 \mathrm{C}$ pyrrhotite.

precipitate is typically described as either mackinawite (FeS) or amorphous iron sulfide, where the term amorphous is dictated by the use of conventional XRD analysis. Depending primarily on redox conditions, the first precipitate may react to form more stable phases such as greigite $\left(\mathrm{Fe}_{3} \mathrm{~S}_{4}\right)$ and pyrite $\left(\mathrm{FeS}_{2}\right)$ (Benning et al., 2000; Cahill et al., 2000; Rickard and Morse, 2005; Pósfai and Dunin-Borkowski, 2006; Hunger and Benning, 2007; Rickard and Luther, 2007). Under certain conditions pyrrhotite $\left(\mathrm{Fe}_{1-} \mathrm{S}\right)$ can also form in anoxic sediments (Horng and Roberts, 2006; Larrasoana et al., 2007) (Table 1). In addition to their geological significance, iron sulfide minerals can be used in soil or water remediation: mackinawite was shown to effectively immobilize heavy metals and toxic ions through sorption mechanisms (Watson et al., 1995; Holmes, 1999; Mullet et al., 2004; Livens et al., 2004; Wolthers et al., 2005; Liu et al., 2008; Gallegos et al., 2008; Renock et al., 2009).

Despite a large number of studies on the formation and phase transitions of iron sulfides, the exact structure and the physical properties of the first precipitate are not satisfactorily known. For the low-temperature synthesis of iron monosulfide, three approaches are commonly used: reacting sulfide with either (1) metallic iron or (2) a ferrous solution, and (3) by using sulfate-reducing bacteria. In general, method 1 leads to crystalline mackinawite with a stoichiometric composition (Lennie et al., 1995; Mullet et al., 2002), whereas processes 2 and 3 result in either ordered mackinawite (Michel et al., 2005; Benning et al., 2000) or disordered, mackinawite-like phases (termed 'FeS ${ }_{\mathrm{am}}$ ' hereinafter) (Wolthers et al., 2003; Shi et al., 2006; Renock et al., 2009; this study). Typically, the XRD patterns of such disordered materials contain a broad peak between $\sim 5$ and $6 \AA$, usually interpreted as indicating an expansion along the $c$ axis relative to that of crystalline mackinawite (Herbert et al., 1998; Ohfuji and Rickard, 2006; Jeong et al., 2008) (Table 2).
In the structure of crystalline mackinawite, the Fe atoms are in the centers of tetrahedra that form sheets parallel to (001) that are held together by van der Waals forces between $S$ atoms (Fig. 1a). In the past, expansion along the $c$ axis of crystalline mackinawite was explained by excess cation uptake between S-S layers (Vaughan and Ridout, 1971). It was also suggested that water molecules can be incorporated between the tetrahedral sheets (Wolthers et al., 2003) or that the expansion may be caused by lattice relaxation due to the small crystallite size (Rickard and Luther, 2007). Wolthers et al. (2003) described $\mathrm{FeS}_{\mathrm{am}}$ as a mixture of two vaguely defined structures, "mkA" and "mkB"; however, the existence of two distinct phases was not confirmed by subsequent studies. The discrepancies between results of similar experiments were also attributed to the difficulty of characterizing nanocrystalline materials and the tendency of the nanocrystals to aggregate (Michel et al., 2005). In addition to the choice of the basic synthesis method (Table 2), the structure of the final product may be affected by various parameters, including the particular source of ferrous iron, the synthesis temperature, and whether wet or dry material is analyzed. Freeze drying can induce some oxidation (Benning et al., 2000). Thus, it is difficult to identify a single factor that is responsible for the formation of "non-mackinawite" $\mathrm{FeS}\left(\mathrm{FeS}_{\mathrm{am}}\right)$.

Magnetic measurements showed that ferrimagnetic greigite can be an important component of anoxic sediments (Roberts, 1995). Although in some cases the initial iron sulfide precipitate was reported to contain greigite alongside mackinawite (Watson et al., 2000; Gramp et al., 2010), it is generally assumed that greigite does not form directly from solution but converts from the pre-existing mackinawite (Hunger and Benning, 2007). The phase transition requires the oxidation of iron and either the addition of sulfur or loss of iron (Horiuchi, 1971; Lennie et al., 1997). Under anhydrous conditions,

Table 2

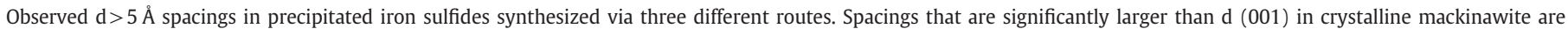

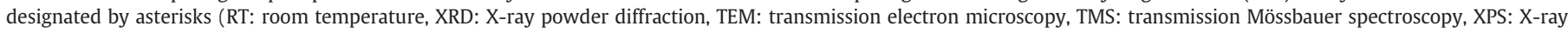

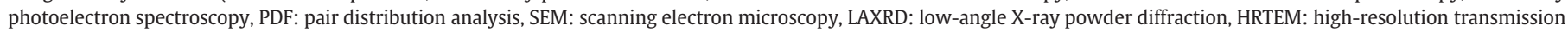
electron microscopy, XAS: X-ray absorption spectroscopy, SAED: selected-area electron diffraction).

\begin{tabular}{|c|c|c|c|c|c|c|}
\hline Synthesis route & $\mathrm{d}(\AA)$ & Reference & $\mathrm{Fe}^{2+}$ source & Temp. of synthesis & Analyzed samples & Methods of analysis \\
\hline \multirow[t]{2}{*}{ Metallic iron } & 5.03 & Lennie et al., 1997 & Iron wire & RT & Dried & XRD \\
\hline & 5.05 & Mullet et al., 2002 & Iron wire & RT & Dried & XRD, TEM, TMS, XPS \\
\hline \multirow[t]{7}{*}{ Ferrous solution } & 5.03 & Michel et al., 2005 & $\left(\mathrm{NH}_{4}\right)_{2} \mathrm{Fe}\left(\mathrm{SO}_{4}\right)_{2} * 6 \mathrm{H}_{2} \mathrm{O}$ & RT & Dried and wet & XRD (PDF), TEM \\
\hline & 5.05 & Benning et al., 2000 & $\left(\mathrm{NH}_{4}\right)_{2} \mathrm{Fe}\left(\mathrm{SO}_{4}\right)_{2} * 6 \mathrm{H}_{2} \mathrm{O}$ & $25-95^{\circ} \mathrm{C}$ & Dried & XRD,SEM \\
\hline & $5.08-5.19^{*}$ & Ohfuji and Rickard, 2006 & $\left(\mathrm{NH}_{4}\right)_{2} \mathrm{Fe}\left(\mathrm{SO}_{4}\right)_{2} * 6 \mathrm{H}_{2} \mathrm{O}$ & RT & Dried & LAXRD, SAED, HRTEM \\
\hline & $5.14^{*}$ & Renock et al., 2009 & $\mathrm{FeCl}_{2}$ & RT & Dried & TEM, XPS \\
\hline & $5.2^{*}$ & Jeong et al., 2008 & $\mathrm{FeCl}_{2}$ & RT & Dried & XRD, XAS, TEM \\
\hline & $5.4^{*}$ & This study & $\mathrm{FeSO}_{4}$ & $70-80{ }^{\circ} \mathrm{C}$ & Dried & XRD, SAED (PDF), HRTEM, SEM \\
\hline & $5.48-6.6^{*}$ & Wolthers et al., 2003 & $\left(\mathrm{NH}_{4}\right)_{2} \mathrm{Fe}\left(\mathrm{SO}_{4}\right)_{2} * 6 \mathrm{H}_{2} \mathrm{O}$ & RT & Dried & LAXRD,TEM, SAED \\
\hline \multirow[t]{2}{*}{ Sulfate-reducing bacteria } & $\sim 5$ & Herbert et al., 1998 & $\mathrm{FeSO}_{4}$ & RT & Dried & XRD, SEM, XPS \\
\hline & $5.7^{*}$ & Watson et al., 2000 & $\mathrm{~N} / \mathrm{A}$ & $32{ }^{\circ} \mathrm{C}$ & Dried & TEM, EXAFS, XANES \\
\hline
\end{tabular}



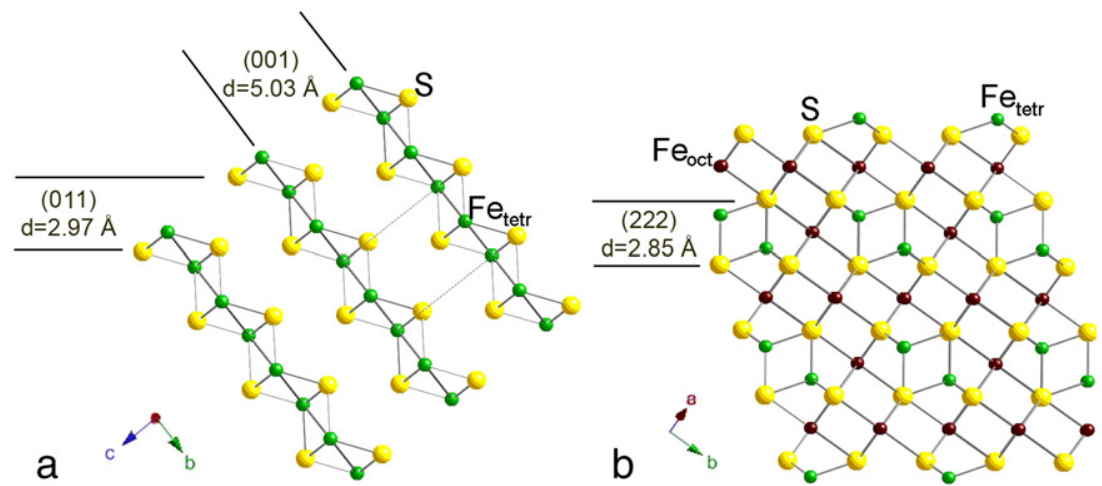

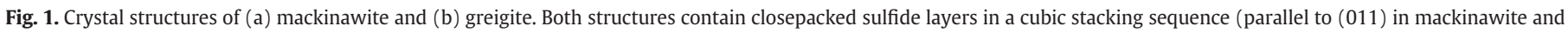
(222) in greigite). Whereas all Fe is in tetrahedral coordination in mackinawite, both octahedral and tetrahedral Fe occur in greigite.

the transformation takes place in the solid state following a topotactic relationship between the two structures (Lennie et al., 1997; Pósfai et al., 1998; Boursiquot et al., 2001), with the preservation of the cubic close-packed sulfide substructure that is the same in mackinawite and greigite (Fig. 1). Conversely, in aqueous solutions, dissolution and reprecipitation processes are likely involved, as greigite formation from mackinawite occurs when conditions become either more oxidizing or when the $\mathrm{pH}$ is lowered (for example, if Eh> -0.1 or $\mathrm{pH}<6$ at $1 \mathrm{mM}$ total $\mathrm{Fe}$ and $\mathrm{S}^{2-}$ concentrations, at $25^{\circ} \mathrm{C}$ and 1 bar pressure) (Benning et al., 2000; Rickard and Luther, 2007). Despite many studies and the importance of iron sulfide phases in past and present environments, the structural details of the aqueous phase transition from the initial precipitate into crystalline mackinawite and greigite, and the changes in crystal morphologies and particle sizes are not well understood.

In this study, we explore the structural and morphological features of precipitated FeS and follow its conversion to mackinawite and greigite. FeS was synthesized from ferrous solutions and then aged both in the supernatant (either at room temperature or by heating the samples up to $170{ }^{\circ} \mathrm{C}$ ) and in the dry state. Here, we report the results of high-resolution electron microscopy and X-ray powder diffraction studies of precipitated FeS and its aging products.

\section{Methods and materials}

\subsection{Synthesis of FeS}

Fresh iron monosulfide precipitates are extremely sensitive to oxygen (Benning et al., 2000), and therefore we synthesized all samples in anaerobic environments. Two types of chambers, one at the University of Pannonia (UP), and another at the University of Leeds (UL) were used. The UP chamber is a plastic $(50 \times 40 \times 50 \mathrm{~cm})$ glovebox in which the $\mathrm{O}_{2}$-free atmosphere was ensured by a continuous flow of $\mathrm{N}_{2}$ gas after all reagents and necessary appliances were inserted into the box. The UL anaerobic chamber is a Freter-type, heavy-duty, flexible PVC chamber (Coy Laboratory Products), with an airlock and a 5:95\% $\mathrm{H}_{2}: \mathrm{N}_{2}$ gas mix and Pt catalysts maintaining anaerobic conditions. The syntheses as well as all subsequent handling of prepared iron sulfide materials were done either in sealed reactors or inside the anaerobic chambers. All reagents were of analytical grade and were used without further purification. Deoxygenated water was used as the starting solvent for all solutions. It was prepared by boiling milliQ water for an hour and bubbling $\mathrm{N}_{2}$ during the heating and cooling periods after which the deoxygenated water was introduced into the chamber.

FeS slurries were precipitated following the methods of Chen et al. (2005). In brief, $100 \mathrm{ml}$ of $0.3 \mathrm{M} \mathrm{Fe}^{2+}$ solution (prepared from $\mathrm{FeSO}_{4} * 7 \mathrm{H}_{2} \mathrm{O}$ ) was mixed with $100 \mathrm{ml}$ of $0.52 \mathrm{M}$ thioacetamide solution $\left(\mathrm{C}_{2} \mathrm{H}_{5} \mathrm{NS}\right)$ in a beaker on a magnetic stirrer. After a few minutes a third solution, $10 \mathrm{ml}$ of deoxygenated, $2.86 \mathrm{M} \mathrm{NaOH}$, was slowly added to raise the $\mathrm{pH}$ to near neutral. In this way a bluish black precipitate formed immediately. This intermediate product could not be identified because of its instability. The covered glass beaker was heated inside the chamber on a hot plate at $70-80{ }^{\circ} \mathrm{C}$ for 40-60 min. This initial aging turned the precipitate inky black. Parts of the samples were mixed with glycerol in order to avoid the oxidation by air while the samples were transferred from the anaerobic chamber to the diffractometer.

\subsection{Aging of FeS}

In order to study the structural and morphological changes associated with the phase transitions of iron sulfides, we aged FeS slurries using two procedures.

(a) Freshly prepared FeS slurries synthesized in the UP chamber were transferred in their original supernatant into sealed beakers (covered with parafilm, watch glass and Al foil), and stored in a dry, dark cupboard for up to 10 months at room temperature. Changes in solid phase compositions were monitored on subsamples removed from the beakers weekly for a month, then about every 2 months. The beakers were transferred back into the glovebox (UP), and samples were collected, filtered and washed several times with deoxygenated water and ethanol after filling the box with nitrogen gas. Then the samples were freeze-dried.

(b) Another aging procedure was used for the samples prepared in the UL chamber. While still inside the anaerobic chamber, aliquots of the freshly synthesized FeS slurries were transferred into Teflon-lined stainless steel Parr reactors. These were sealed, and after removal from the anaerobic chamber they were reacted in a pre-heated oil bath or oven for 2,5 , and $12 \mathrm{~h}$ at temperatures of 120,150 and $170{ }^{\circ} \mathrm{C}$. After the set time, the reactors were quenched to $25^{\circ} \mathrm{C}$ and transferred back into the anaerobic chamber (UL). The solutions were filtered, and the resulting solids washed with deoxygenated water and ethanol and then freezedried. These high-temperature freeze-dried samples were sealed in triple-contained $\mathrm{N}_{2}$-filled vials and stored in gas-tight plastic bags filled with $\mathrm{N}_{2}$ for up to 3 months. Subsets of these samples were used for high-resolution electron microscopy, and the remainders of the samples were again analyzed by X-ray powder diffraction after 3 months of storage under dry and anaerobic conditions in order to evaluate the dry transformation processes.

\subsection{Solid characterization}

The structures, compositions, particle sizes and morphologies of the resulting solid samples were studied using X-ray powder 
diffraction (XRD) and scanning and transmission electron microscope techniques (SEM and TEM, respectively). XRD patterns were obtained using Philips PW1710 and PW1050 diffractometers (CuK $\alpha$ radiation, scanning rate $1-2^{\circ} / \mathrm{min}$, step size $0.01^{\circ}, 2 \Theta$ range $\left.5-65^{\circ}\right)$. The relative percentages of the phases in each XRD pattern were derived by Rietveld refinement using the TOPAS software version 4.2 (copyright 1999-2009 Bruker AXS) and available structural data for the mineral phases. SEM images were recorded either on a conventional (JEOL JSM-5800, $20 \mathrm{keV}$ ) or a field-emission-gun electron microscope (FEG-SEM, LEO 1530 Gemini, $3 \mathrm{keV}$ ). Bright-field TEM images and selected-area electron diffraction (SAED) patterns were recorded on image plates, using a Philips CM20 microscope operated at $200 \mathrm{kV}$ and fitted with a Noran Voyager energy-dispersive X-ray detector. For obtaining atomic distances from SAED patterns, integrated diffracted intensities $\left(I_{\text {exp }}\right)$ were retrieved using the ProcessDiffraction software (Lábár, 2005). $I_{\text {exp }}$ was then used for obtaining the reduced interference function $(Q \cdot i(Q))$, according to the equation $Q \cdot i(Q)=$ $Q \cdot\left(I_{\text {exp }}-<f^{2}>\right) /<f>^{2}$, where $f$ is the atomic scattering factor for electrons, and the scattering angle $Q=4 \pi \sin \theta / \lambda$ (where $\theta$ and $\lambda$ are the Bragg angle and the wavelength of the electron beam, respectively). Then the Fourier transform of $Q \cdot i(Q)$ was calculated, resulting in the reduced correlation function $G(r)=4 \pi r \rho_{o}[g(r)-1]$, where $\rho_{0}$ is the average density of the material, and $g(r)$ is the pair distribution function (PDF). Since $g(r)=\rho(r) / \rho_{0}$, where $\rho(r)$ is the density at $r$ distance from the origin, the PDF is essentially a frequency distribution of individual atomic distances. High-resolution transmission electron microscopy (HRTEM) was performed using either a JEOL 3010 or a JEOL 2010F microscope (operated at 297 and $200 \mathrm{kV}$, respectively). For the XRD and TEM data processing CrystalDiffract, CrystalMaker, ProcessDiffraction and DigitalMicrograph were used.

\section{Results}

The same chemical reactions performed in two different anaerobic chambers resulted in different products. Whereas $\mathrm{FeS}_{\mathrm{am}}$ was produced in the UP chamber, nanocrystalline mackinawite formed in the fully anoxic UL chamber. Therefore, the two sets of samples are discussed separately.

\subsection{Precipitated iron sulfide $\mathrm{FeS}_{a m}(U P)$}

Conventional XRD suggested that the initial precipitate was poorly ordered, as evidenced by a sole broad band in the XRD pattern at $2 \Theta=16.5^{\circ}$ (Fig. 2). This band corresponds to a d-spacing of $5.4 \AA$, which is significantly larger than the $d(001)$ of crystalline mackinawite $(5.03 \AA$ ) (Table 2). Peaks at the positions of otherwise intense 011, 111 and 112 reflections of mackinawite, as well as those corresponding to greigite were absent. Smaller peaks showing the presence of minor amounts (with the error of analysis taken into account, $<5 \%$ ) of elemental sulfur and goethite are artifacts from oxidation during sample transfer and aerobic XRD analyses.

$\mathrm{FeS}_{\mathrm{am}}$ has a characteristic microstructure, consisting of several $\mu \mathrm{m}$-large aggregates of curved, wrinkled sheets that are $\sim 65-85 \mathrm{~nm}$ thick (Fig. 3a and b). Edge-on views of the curved sheets (Fig. 3c) reveal that their central unit consists of 3-8 semi-ordered atomic layers. These central units are coated by completely amorphous material, the wavy, fluffy surface of which can also be observed in high-resolution SEM images. While the structures of semi-ordered layers can be studied in HRTEM images, the embedding, amorphous material can be characterized on the basis of SAED patterns.

The basically amorphous character of the material is reflected by SAED patterns obtained from entire aggregates that typically contain only faint, diffuse rings at $\sim 2.4$ and $1.4 \AA$, and in some patterns at 5.7-6 A. These values are inconsistent with the mackinawite structure. Distributions of atomic distances, obtained from pair distribution function (PDF) analysis of two SAED patterns (Fig. 4), show two prominent peaks at $\sim 2.1$ and $3.45 \AA$ (the first, unmarked peak in the distribution is an artifact from data processing). The $2.1 \AA$ peak can be interpreted as resulting from the Fe-S distance if iron is tetrahedrally coordinated, and the $3.45 \AA$-peak is consistent with S-S distances. No distinct peaks appear beyond $\sim 7 \AA$, suggesting no correlation between atoms beyond this distance. Thus, the bulk of $\mathrm{FeS}_{\mathrm{am}}$ can be regarded as consisting of a completely disordered arrangement of $\left[\mathrm{FeS}_{4}\right]$ tetrahedra.

HRTEM images show distinct features at the cores of the amorphous sheets that consist of a few atomic layers (Fig. 3c). The spacing between these layers varies from $\sim 5.3$ up to $6.3 \AA$, and the layer stacking does not appear to follow any ordered pattern. In the HRTEM images, the contrast of each individual atomic layer consists

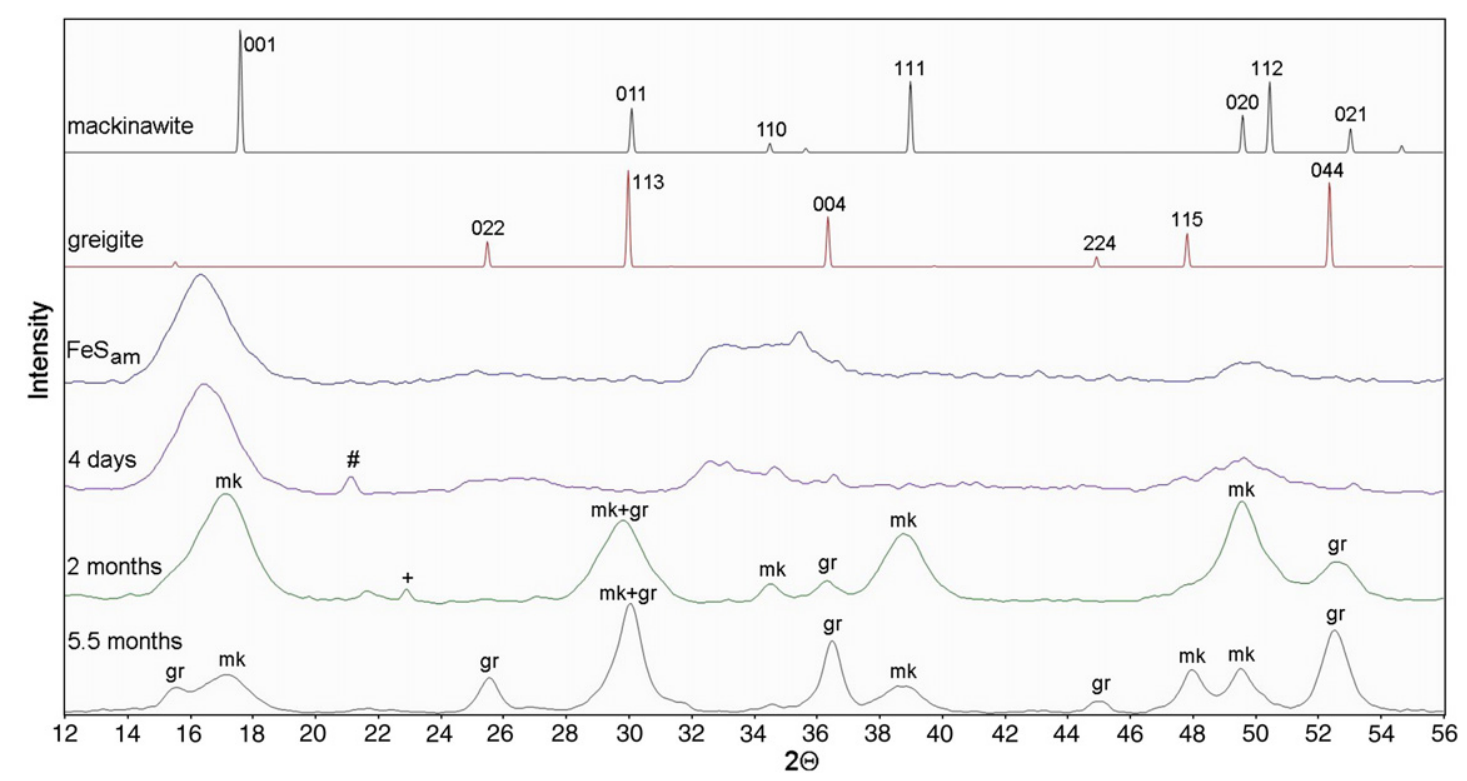

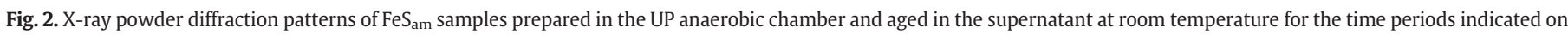
each spectrum. On top are calculated patterns for mackinawite and greigite (mk: mackinawite; gr: greigite; \# and + mark goethite and elemental sulfur peaks, respectively). 

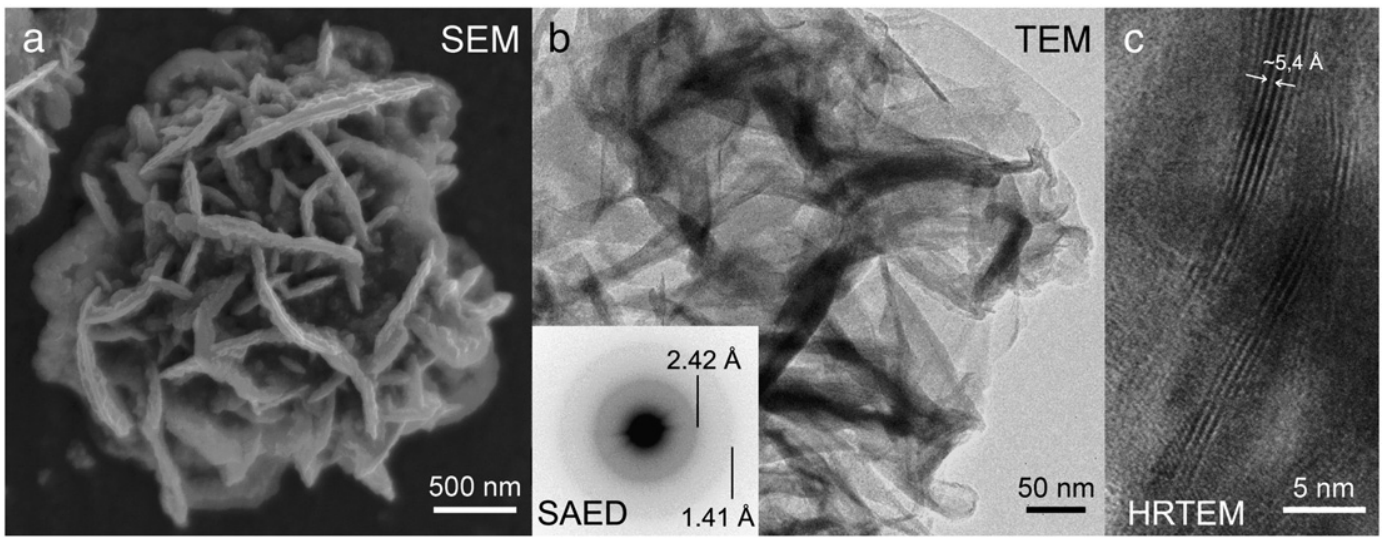

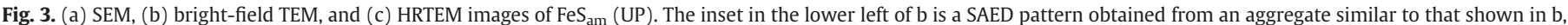

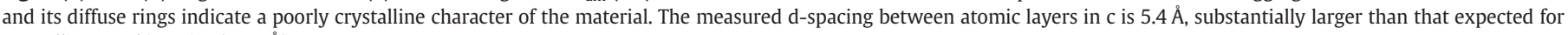
crystalline mackinawite (5.03 $\AA$ ).

of a series of white dots, suggesting an ordered structure. The spacings between the white dots within individual atomic layers may vary to some extent but are typically between $\sim 3$ and $3.1 \AA$ (Fig. 5). In places where the iron sulfide sheets are perpendicular to the electron beam, no atomic ordering could be observed in the HRTEM images. The absence of intense phase contrast conditions in this view results from both in-plane and interplanar structural disorder.

\subsection{Aging of FeS ${ }_{a m}$ in the supernatant (UP)}

The XRD patterns of the aged $\mathrm{FeS}_{\text {am }}$ showed distinct changes as a function of time, regarding both the presence and the proportion of phases (Fig. 2 and Table 3). After 2 months at room temperature, the broad band at $2 \Theta \sim 16.5^{\circ}$ shifted, approaching the value for the 001 reflection of crystalline mackinawite (5.03 $\AA$ ), and other mackinawite peaks appeared (i.e., 011, 110, 111, 200). In addition, small greigite peaks appeared after 2 months. According to quantitative analyses, the proportion of greigite increased from $\sim 18$ to $65 \%$ between 2 and 5.5 months aging (Table 3). A SAED pattern of the 5.5-month-old sample (Fig. 6) illustrates the simultaneous occurrence of mackinawite and greigite in the same aggregate. Subsequently, the amount of greigite further increased, reaching $100 \%$ in the 10 -month-old sample (Table 3). The greigite in this final sample formed aggregates of

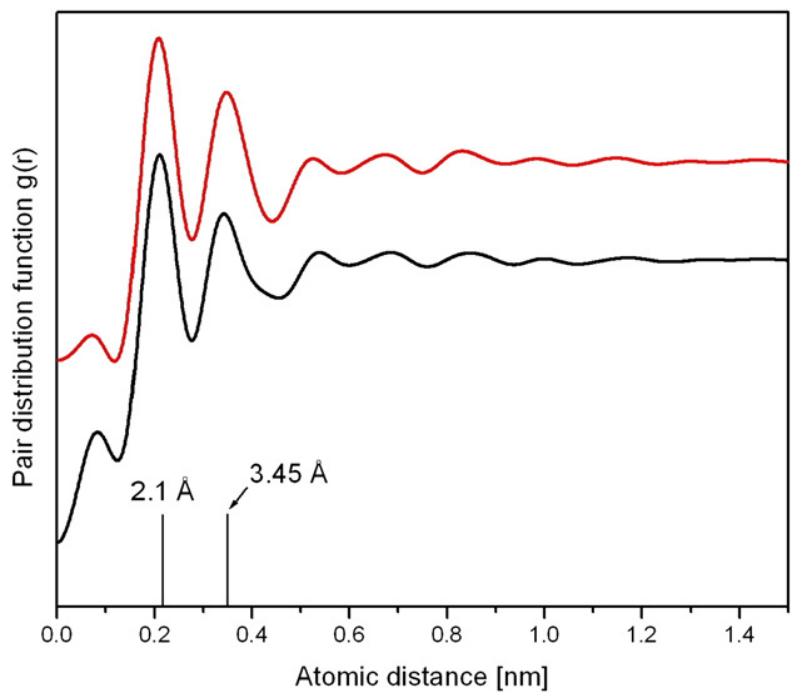

Fig. 4. Pair distribution functions (PDFs) calculated from two SAED patterns obtained from $\mathrm{FeS}_{\mathrm{am}}$. The two peaks at $\sim 2.1$ and $3.45 \AA$ are consistent with $\mathrm{Fe}-\mathrm{S}$ and S-S distances in $[\mathrm{FeS}]_{4}$ tetrahedra, respectively. crystalline platelets that were up to $\sim 150 \mathrm{~nm}$ wide but only a few $\mathrm{nm}$ thick (Fig. 7a and b), much smaller and thinner than the amorphous sheets in $\mathrm{FeS}_{\mathrm{am}}$. Furthermore, the platelets had straight edges and surfaces, and neither mackinawite, nor amorphous $\mathrm{FeS}_{\mathrm{am}}$ was associated with them, as confirmed by HRTEM images and SAED patterns (Fig. 7c).

\subsection{Precipitated FeS mackinawite (UL)}

The structure of FeS prepared in the UL anaerobic chamber clearly differs from that of $\mathrm{FeS}_{\mathrm{am}}$. XRD patterns obtained form the freshly

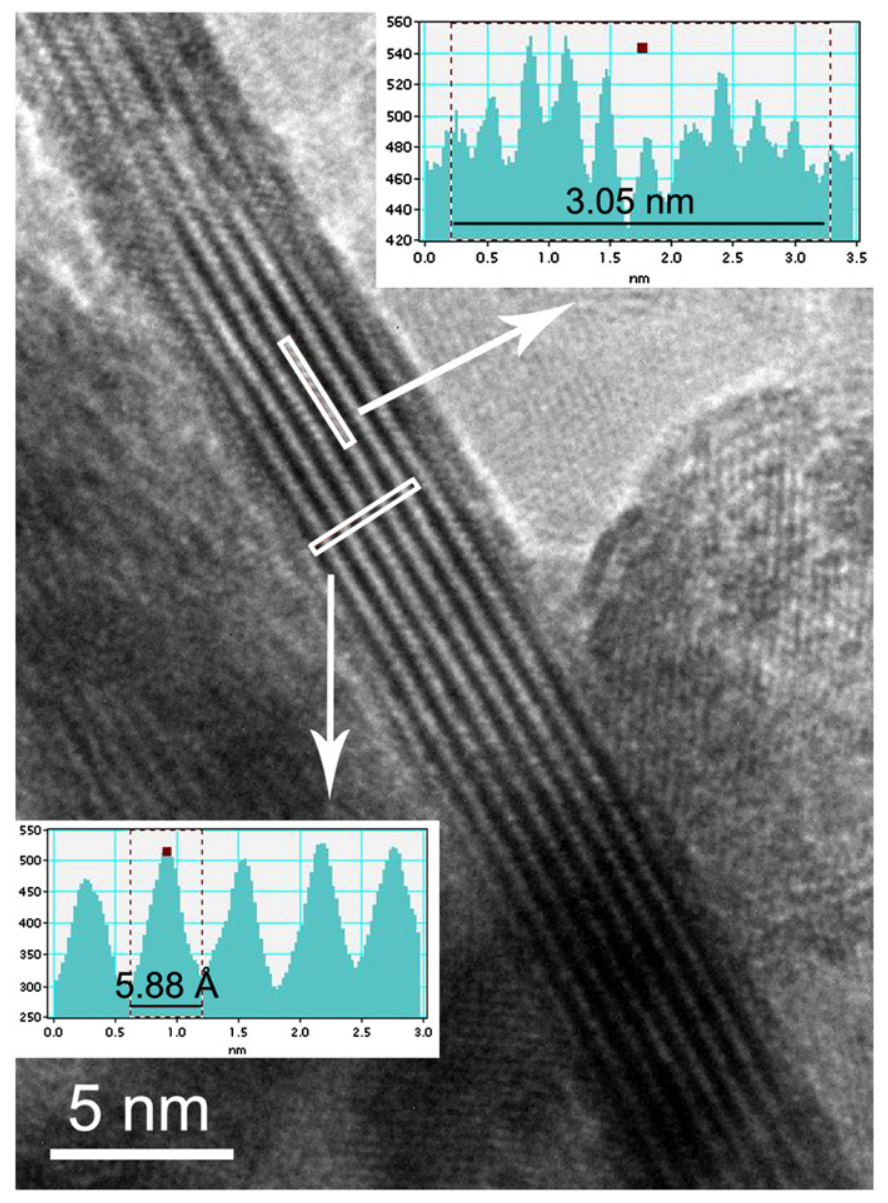

Fig. 5. HRTEM edge-on view of a typical sheet in $\mathrm{FeS}_{\mathrm{am}}$. Spacings within and between the layers are $\sim 3.05$ and $\sim 5.9 \AA$, as illustrated by the intensity profiles in the upper right and lower left, respectively. 
Table 3

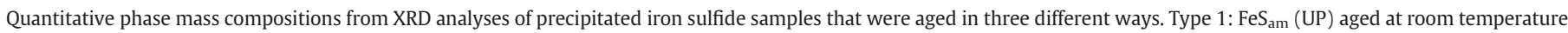

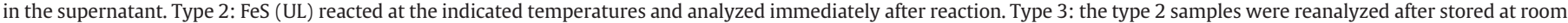

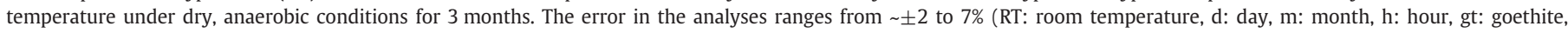
S: sulfur).

\begin{tabular}{|c|c|c|c|c|c|c|}
\hline \multicolumn{2}{|c|}{ Condition, temperature and duration of aging } & \multirow{2}{*}{$\begin{array}{l}\mathrm{FeS}_{\mathrm{am}}(\%) \\
100\end{array}$} & \multirow{2}{*}{$\begin{array}{l}\text { Mackinawite (\%) } \\
-\end{array}$} & \multirow{2}{*}{$\begin{array}{l}\text { Greigite (\%) } \\
-\end{array}$} & \multirow[t]{2}{*}{ Pyrrhotite (\%) } & \multirow{2}{*}{$\begin{array}{l}\text { Others }(\%) \\
\text { gt }(<2)\end{array}$} \\
\hline Type 1 & Wet, RT, 4 d & & & & & \\
\hline & Wet, RT, 14 d & 100 & - & - & & Minor gt and $\mathrm{S}$ \\
\hline & Wet, RT, 2 m & - & 82 & 18 & & $\mathrm{~S}(<2)$ \\
\hline & Wet, RT, $5.5 \mathrm{~m}$ & - & 35 & 65 & & - \\
\hline & Wet, RT, 7.5 m & - & 44 & 56 & & - \\
\hline & Wet, RT, 10 m & - & - & 100 & & Minor gt and $\mathrm{S}$ \\
\hline \multirow[t]{8}{*}{ Type 2} & Wet, $120^{\circ} \mathrm{C}, 2 \mathrm{~h}$ & & 100 & - & - & - \\
\hline & Wet, $120^{\circ} \mathrm{C}, 5 \mathrm{~h}$ & & 100 & - & - & - \\
\hline & Wet, $120^{\circ} \mathrm{C}, 12 \mathrm{~h}$ & & 100 & - & - & - \\
\hline & Wet, $150^{\circ} \mathrm{C}, 2 \mathrm{~h}$ & & 74 & - & 26 & - \\
\hline & Wet, $150{ }^{\circ} \mathrm{C}, 5 \mathrm{~h}$ & & 62 & - & 38 & - \\
\hline & Wet, $150{ }^{\circ} \mathrm{C}, 12 \mathrm{~h}$ & & - & - & 100 & - \\
\hline & Wet, $170^{\circ} \mathrm{C}, 2 \mathrm{~h}$ & & - & - & 100 & - \\
\hline & Wet, $170{ }^{\circ} \mathrm{C}, 5 \mathrm{~h}$ & & - & - & 100 & - \\
\hline \multirow[t]{8}{*}{ Type 3} & Wet, $120^{\circ} \mathrm{C}, 2 \mathrm{~h}+$ dry, RT, $3 \mathrm{~m}$ & & - & 92 & 9 & - \\
\hline & Wet, $120^{\circ} \mathrm{C}, 5 \mathrm{~h}+$ dry, RT, $3 \mathrm{~m}$ & & 7 & 83 & 7 & $S(\sim 3)$ \\
\hline & Wet, $120^{\circ} \mathrm{C}, 12 \mathrm{~h}+$ dry, RT, $3 \mathrm{~m}$ & & 19 & 69 & 11 & - \\
\hline & Wet, $150^{\circ} \mathrm{C}, 2 \mathrm{~h}+$ dry, RT, $3 \mathrm{~m}$ & & 5 & 63 & 32 & $\mathrm{~S}(\sim 1)$ \\
\hline & Wet, $150^{\circ} \mathrm{C}, 5 \mathrm{~h}+$ dry, RT, $3 \mathrm{~m}$ & & 6 & 42 & 52 & - \\
\hline & Wet, $150^{\circ} \mathrm{C}, 12 \mathrm{~h}+$ dry, RT, $3 \mathrm{~m}$ & & - & 2 & 98 & - \\
\hline & Wet, $170{ }^{\circ} \mathrm{C}, 2 \mathrm{~h}+$ dry, RT, $3 \mathrm{~m}$ & & - & 2 & 98 & - \\
\hline & Wet, $170{ }^{\circ} \mathrm{C}, 5 \mathrm{~h}+$ dry, RT, $3 \mathrm{~m}$ & & - & 2 & 98 & - \\
\hline
\end{tabular}

precipitated material either did not show any peaks at all or were consistent with the structure of mackinawite. Significantly, if the 001 peak was present, it appeared at the position expected for ordered mackinawite. SEM images (Fig. 8) show aggregates of curved platelets that are much smaller and thinner than the sheets in $\mathrm{FeS}_{\mathrm{am}}$ (Fig. 3a). No amorphous coating is apparent on the platelets. Based on these results, the precipitated FeS can be identified as nanocrystalline mackinawite.

\subsection{Aging of FeS by heating (UL)}

The aging of FeS slurries by heating resulted in (a) faster transformation rates and (b) partly different iron sulfide phases than the roomtemperature aging experiments of $\mathrm{FeS}_{\mathrm{am}}$. When reacted at $120^{\circ} \mathrm{C}$ for only $2 \mathrm{~h}$, the sole resulting mineral phase was crystalline mackinawite as indicated by the presence of all mackinawite reflections at their calculated positions in the XRD pattern (Table 3; Fig. 9). TEM images of the 2-hour, $120^{\circ} \mathrm{C}$ sample (recorded after storage under $\mathrm{N}_{2}$ for several days) showed crystalline platelets that were $\sim 10$ to $500 \mathrm{~nm}$ long (Fig. 10a). SAED patterns (Fig. 10b) indicated that the sample contained minor greigite in addition to the major phase, mackinawite.

XRD patterns obtained immediately after reacting FeS at 150 and $170{ }^{\circ} \mathrm{C}$, showed mixtures of mackinawite and hexagonal pyrrhotite with no greigite (Table 3; Fig. 9). With increased reaction time, pyrrhotite became the only product. Consistent with these XRD results, euhedral hexagonal iron sulfide, presumably pyrrhotite, was observed in SEM images (Fig. 11a), and pyrrhotite was identified in SAED patterns (Fig. 11c). Although the XRD evaluation indicated no greigite in any of the 150 and $170{ }^{\circ} \mathrm{C}$ samples, a few euhedral crystals with cubic morphologies and an iron-sulfur composition were observed in SEM images (Fig. 11b) and tentatively identified as greigite. Furthermore, SAED patterns of the same samples obtained after a few days storage in a dry state under $\mathrm{N}_{2}$ also confirmed the presence of greigite and even troilite (Fig. 11e and d, respectively).

\subsection{Dry aging of heated samples under anaerobic conditions (UL)}

The high-temperature samples were stored for 3 months under anaerobic conditions and then reanalyzed with XRD. Samples that were prepared at $120{ }^{\circ} \mathrm{C}$ and originally contained $100 \%$ mackinawite almost completely converted to greigite and pyrrhotite (Table 3; Fig. 9). In the samples that originally contained both mackinawite and pyrrhotite (heated at $150{ }^{\circ} \mathrm{C}$ for 2 and $5 \mathrm{~h}$ ), mackinawite converted to greigite, while the proportion of pyrrhotite remained almost unchanged. Samples that consisted of pyrrhotite only (prepared at 150 and $170{ }^{\circ} \mathrm{C}$ ), were stable during storage and showed no significant changes (Table 3 ).
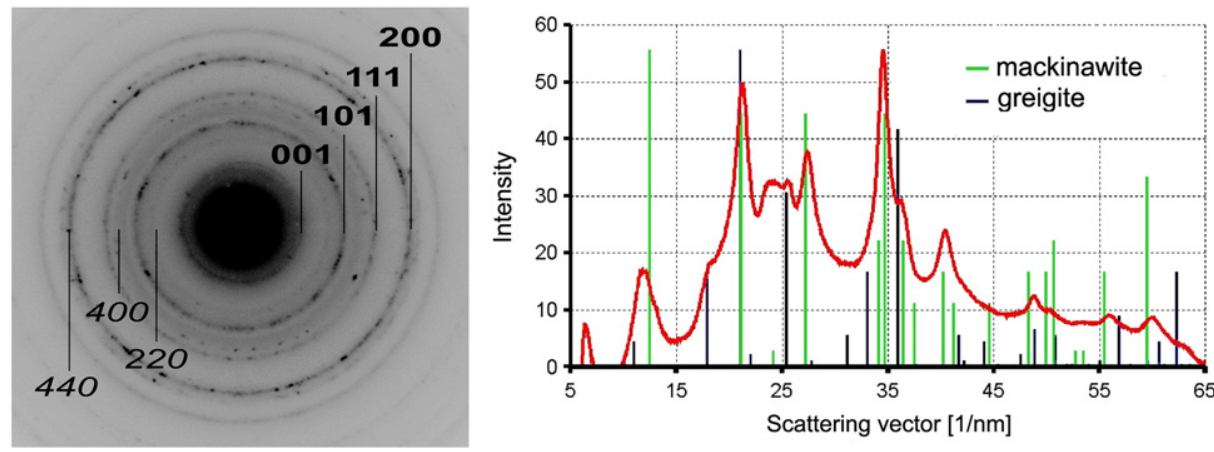

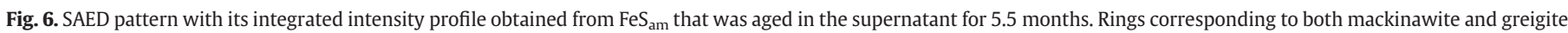
spacings are present, as indicated by Miller-indices in bold and italics in the SAED pattern, respectively. 

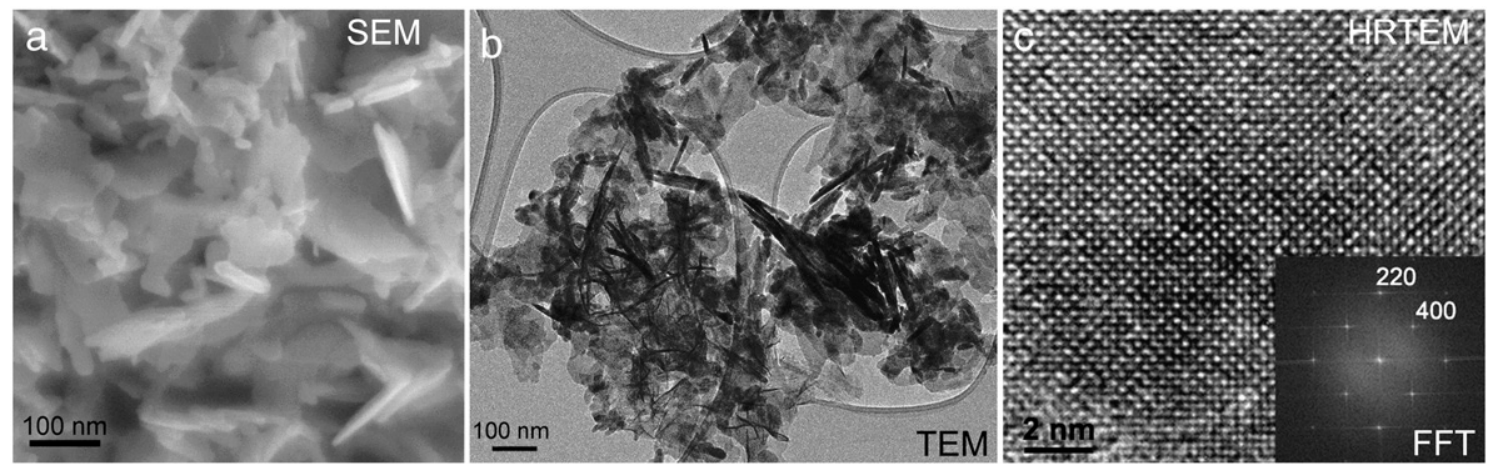

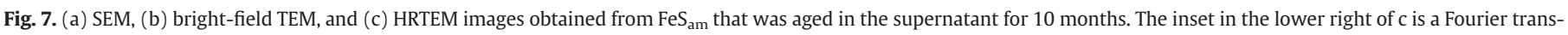
form of the HRTEM image and is consistent with the structure of greigite.

\section{Discussion and conclusions}

\subsection{Structure and particle size of precipitated FeS}

The structure of the first precipitate was reported in the literature either as amorphous or as consistent with that of crystalline mackinawite. In most cases, reactions with ferrous solutions resulted in poorly crystalline or amorphous precipitates, whereas reactions with metallic iron produced mackinawite (Table 2). It was noted by several authors that the material is extremely fine-grained and aggregated, and therefore difficult to characterize. In addition, the structure of the freshly precipitated material was shown to be very sensitive to small changes in pH (Harmandas and Koutsoukos, 1996; Wolthers et al., 2003), minor amounts of atmospheric oxygen (Hunger and Benning, 2007), and slight oxidation during freeze-drying (Benning et al., 2000). Apparently, subtle changes in reaction conditions can result in the precipitation of either amorphous ('poorly crystalline') $\mathrm{FeS}_{\mathrm{am}}$ or crystalline mackinawite. Another important variable that affects how the material is described is the choice of the analysis technique; in some cases, the same material appears to be amorphous with conventional XRD but turns out to be crystalline mackinawite (albeit with $<3 \mathrm{~nm}$ grain size), when identified using PDF analysis of synchrotron XRD patterns (Michel et al., 2005). Here, we distinguish $\mathrm{FeS}_{\mathrm{am}}$ as the material that produces a broad but pronounced peak in conventional XRD patterns at d-values larger than $\sim 5.1 \AA$.

In this study we synthesized FeS from ferrous solutions, and the resulting precipitate was either nanocrystalline mackinawite (UL) or $\mathrm{FeS}_{\mathrm{am}}$ (UP). Since the same reaction was performed in both anaerobic chambers, the difference in the results is likely attributable to differences in redox conditions. Our product phases and observations during synthesis (such as the appearance of a pale yellow color of

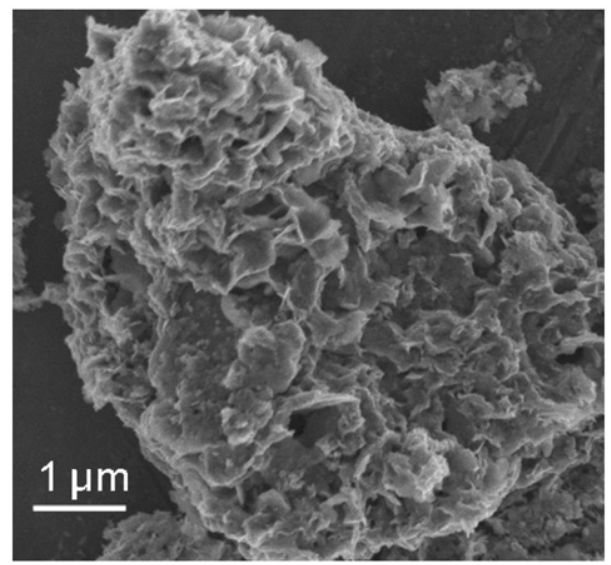

Fig. 8. SEM image of freshly precipitated nanocrystalline mackinawite, synthesized under fully anoxic conditions in the UL anaerobic chamber. the solution) suggest that a slight, unquantified amount of oxidation might have occurred in the glovebox at the UP. On aging $\mathrm{FeS}_{\mathrm{am}}$, we observed the formation of greigite; according to Schoonen and Barnes (1991b), greigite forms only when conditions are not completely anoxic. Thus, our synthesis and aging conditions at the UP and the product $\mathrm{FeS}_{\mathrm{am}}$ could be representative of natural settings in which anoxic sediments are exposed to slightly oxidizing conditions. In contrast, nanocrystalline mackinawite appears to be the first FeS precipitate under fully anoxic conditions, such as maintained in the anaerobic chamber at UL. Whereas mackinawite has a welldefined and known structure (Lennie et al., 1995), $\mathrm{FeS}_{\mathrm{am}}$ does not. Therefore, in the following we discuss our results concerning FeS $\mathrm{am}_{\mathrm{am}}$.

The observed d-spacing of $5.4 \AA$ in $\mathrm{FeS}_{\mathrm{am}}$ is far larger than $\mathrm{d}$ (001) in crystalline mackinawite. Similar d-values were observed by several other authors (Table 2) and attributed to a structure consisting of mackinawite (001)-type sheets but lacking an ordered stacking of the sheets along the [001]-direction (Herbert et al., 1998; Ohfuji and Rickard, 2006). The identification of the sheet-like features as mackinawite-type structural elements appears to be mainly based on indirect experimental or modeling evidence: (a) the structural homology between suggested aqueous $\mathrm{Fe}_{2} \mathrm{~S}_{2}$ clusters and the $\mathrm{Fe}$ coordination in crystalline mackinawite (Rickard and Luther, 2007), (b) the layered structure and very stable (001) surface of crystalline mackinawite (Devey et al., 2009), and (c) the fact that $\mathrm{FeS}_{\mathrm{am}}$ converts to mackinawite upon aging.

In our HRTEM images obtained from $\mathrm{FeS}_{\mathrm{am}}$, two distinct spacings were measured: the distances between the wavy layers and those between the quasi-periodic contrast features (white dots) within the individual layers. None of these spacings are consistent with the structure of mackinawite. Within the layers, distances from $\sim 3$ to 3.1 Å are typical (Fig. 5). Our HRTEM image simulations of mackinawite indicate that under a wide range of specimen thickness and objective lens defocus values, the distances between strong, intralayer contrast features are associated with the spacings of $\mathrm{Fe}$ positions that are 2.6 A apart, when viewed along [110] (not shown). The projected Fe-Fe spacings are even smaller in other orientations that are perpendicular to $c$. On the other hand, the distances between octahedral Fe atoms within a close-packed sheet are 3.05 and $3.0 \AA$ in greigite and pyrrhotite, respectively. Thus, the measured intralayer 3-3.1 A distances in $\mathrm{FeS}_{\text {am }}$ suggest the presence of octahedrally coordinated Fe atoms between close-packed sulfide layers instead of a mackinawite-like tetrahedral coordination of Fe.

The average distance between the individual layers of our initial precipitate $\mathrm{FeS}_{\mathrm{am}}$ is best reflected by the $\sim 5.4 \AA$ peak in the XRD pattern. In HRTEM micrographs we measured layer distances between $\sim 5.3$ and 6.3 Å. Various causes were proposed for the expansion of this spacing relative to the $\mathrm{d}(001)$ of crystalline mackinawite, including the incorporation of either water molecules or oxygen between the (001) sheets (Wolthers et al., 2003). X-ray photoelectron spectroscopy studies identified $\mathrm{Fe}$ (III), presumably in greigite-like 


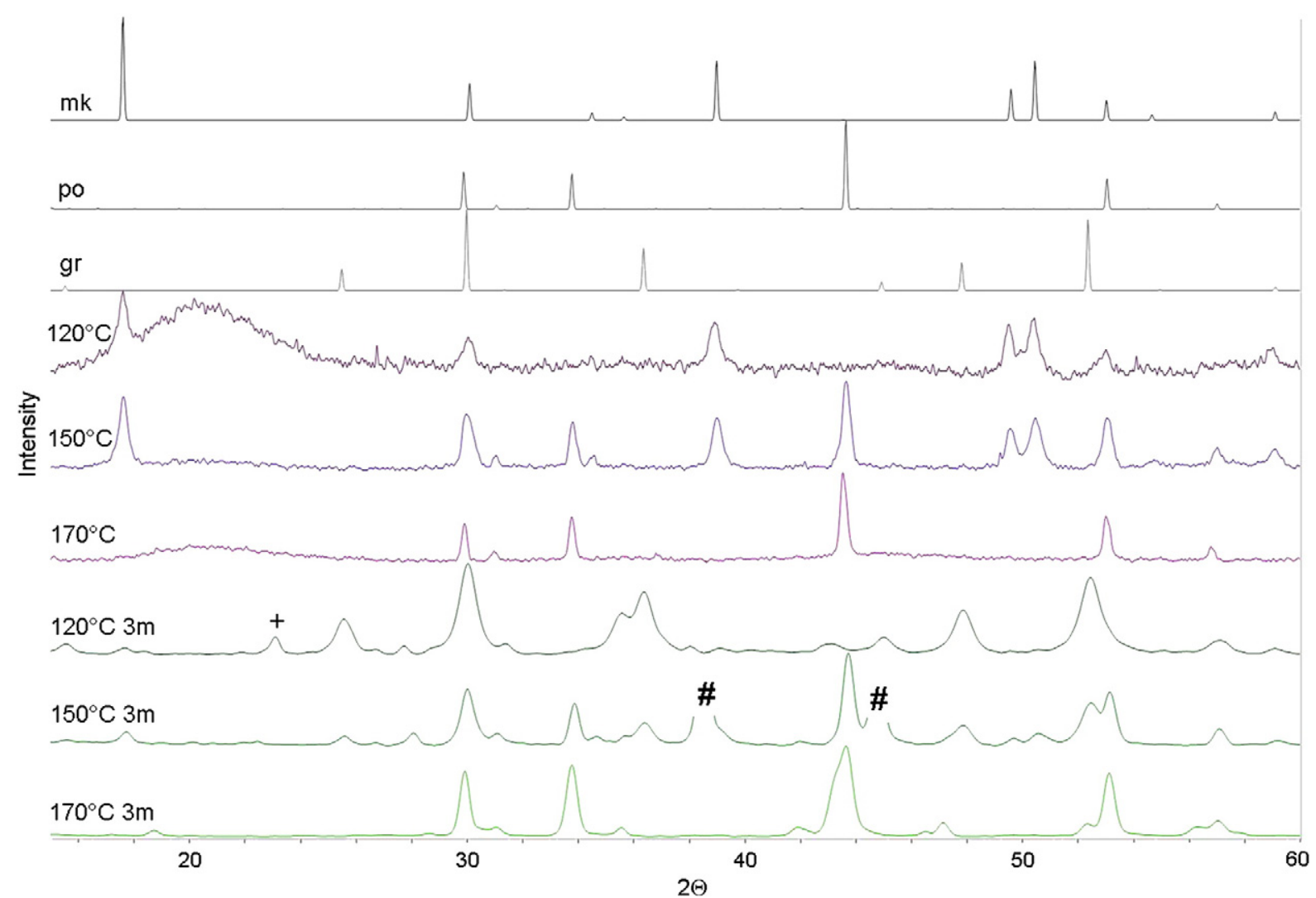

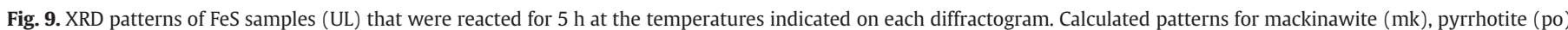

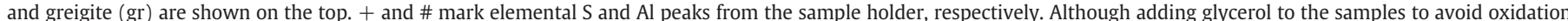
was successful, this procedure resulted in a large background in the $2 \Theta$ range of $18-24^{\circ}$ for some samples.

octahedral coordination, both on the surfaces of mackinawite (Mullet et al., 2002) and in poorly crystalline FeS (Herbert et al., 1998). It is tempting to describe the observed few-layer-thick sheets as hydrated sulfide analogs of metal hydroxides; however, SH groups were never detected by spectroscopic analyses of samples that can be regarded equivalent to $\mathrm{FeS}_{\mathrm{am}}$ (Rickard and Luther, 2007). It also cannot be
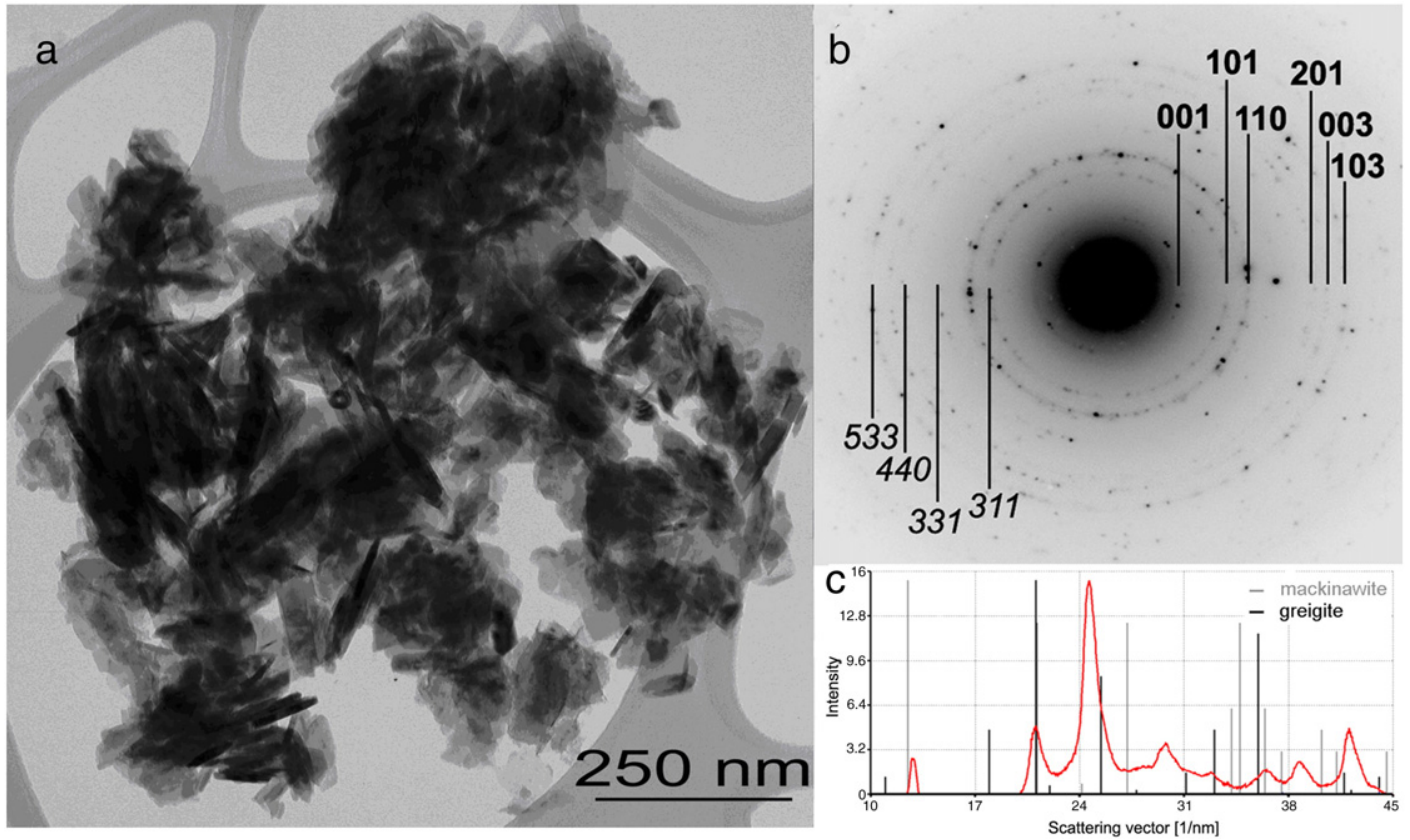

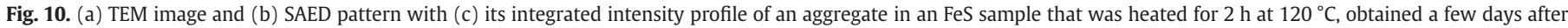

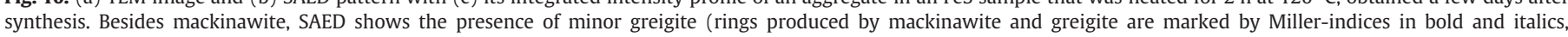
respectively). 


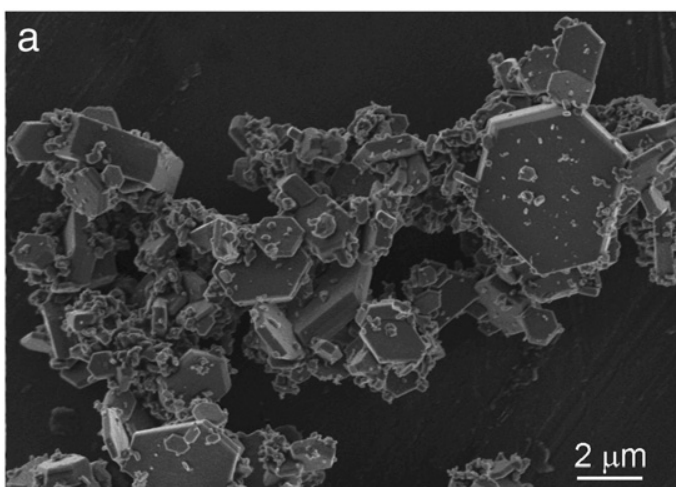

C d

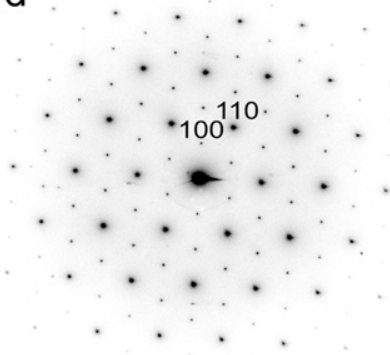

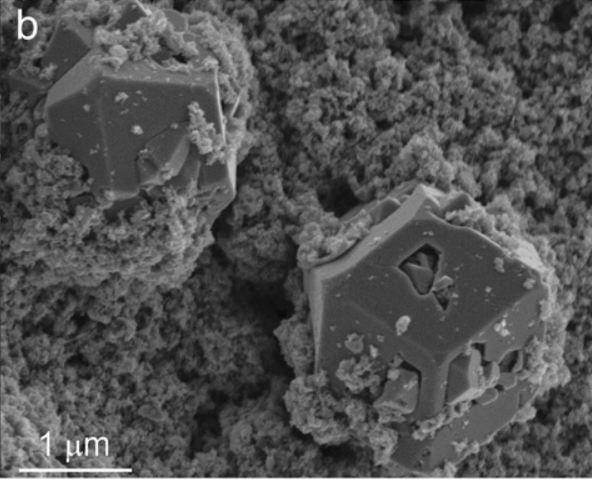

e
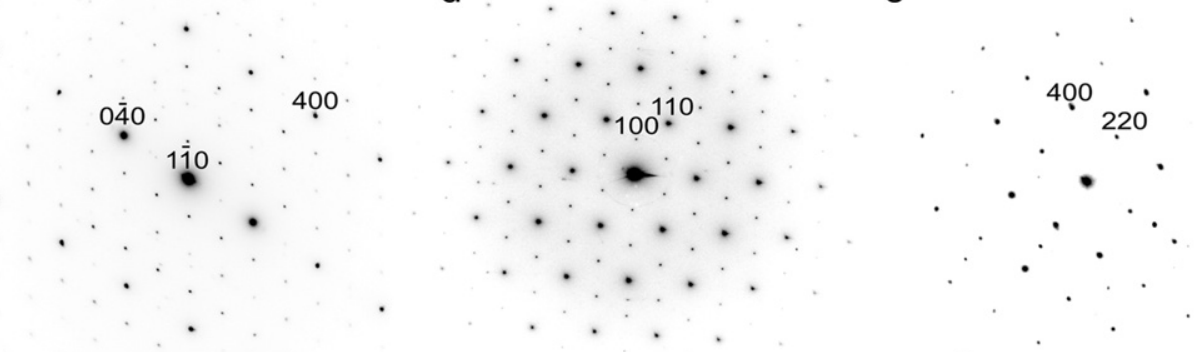

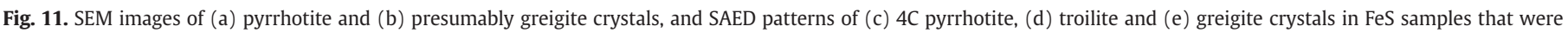
heated at $150{ }^{\circ} \mathrm{C}$ for $5 \mathrm{~h}$.

excluded that simply the disordered stacking of curved layers results in weaker van der Waals bonds and larger distances between layers. At present, we can only speculate that individual layers within the characteristic sheet-like features in $\mathrm{FeS}_{\mathrm{am}}$ consist of octahedrally coordinated Fe atoms between the close-packed, perhaps hydrated sulfide layers. In any case, our results strongly suggest that nonmackinawite-like structural units occur in $\mathrm{FeS}_{\mathrm{am}}$.

Even though the semi-ordered layers discussed above are prominent features in HRTEM images, most of the volume of $\mathrm{FeS}_{\mathrm{am}}$ is amorphous, as indicated by SAED patterns. PDF analysis of SAED patterns suggests that the bulk of FeS ${ }_{\mathrm{am}}$ consists of Fe tetrahedrally coordinated by $\mathrm{S}$, but any order breaks down beyond $\sim 6-7 \AA$ (Fig. 4). Thus, the entire material can be regarded as sheets consisting of a few atomic-layer-thick, semiordered layers at their cores, covered by thick, amorphous FeS in which Fe is in tetrahedral coordination.

A consensus on the particle size of precipitated FeS is lacking. A wide range of values can be found in the literature, depending on whether BET, XRD or HRTEM was used for particle size determination (as discussed by Rickard and Luther, 2007). Coherently diffracting domains were found to be only a few nm large (Michel et al., 2005), consistent with TEM observations of Jeong et al. (2008). Ohfuji and Rickard (2006) also measured particle lengths of 3 to $11 \mathrm{~nm}$ on the basis of visible lattice fringes in HRTEM images. While this method is useful for determining the coherently diffracting domain size, it does not provide information about the dimensions of the curved, sheet-like features because the fringes can go out of contrast as a result of the bending of sheets. In light of our results, in the case of $\mathrm{FeS}_{\mathrm{am}}$, it is almost meaningless to attempt to determine particle sizes, since the material is a complex aggregate of interwoven, curved, sheet-like features, and within the aggregates it is difficult to define the actual particle dimensions (Fig. 3). Nevertheless, the sizes of poorly-ordered, presumably coherently-diffracting domains observed with HRTEM are consistent with the few nm-sized particles described in most previous studies. In the case of nanocrystalline mackinawite (Fig. 10a), our crystal size dimensions of $10-500 \mathrm{~nm}$ are consistent with earlier reports (Taylor et al., 1979; Kornicker, 1988; Rickard and Luther, 1997; Benning et al., 2000; Wolthers et al., 2003).

\subsection{Phase transformations}

\subsubsection{Aqueous transformation of $\mathrm{FeS}_{\mathrm{am}}$ into greigite}

$\mathrm{FeS}_{\mathrm{am}}$ that was reacted in a solution at room temperature slowly converted to greigite. Intermediate products contained both greigiteand mackinawite-type structural units, as indicated by both XRD and SAED patterns (Figs. 2 and 6). The amorphous material gradually disappeared and after 10 months the entire sample turned into crystalline greigite (Table 3 ). The driving force for the phase transition was probably the presence of excess sulfur in the form of polysulfides that partly oxidized Fe (II) (Hunger and Benning, 2007). The transformation was slow because the solution had a nearly neutral $\mathrm{pH}$, and greigite preferentially forms from mackinawite under more acidic and oxidizing conditions (Schoonen and Barnes, 1991b; Rickard and Luther, 2007). Interestingly, at the time resolution of our experiments, samples consisting of only mackinawite were never observed. Thus, in an aqueous, sulfidic environment the $\mathrm{FeS}_{\mathrm{am}}$ produced using our method converts to greigite through an intermediate state that can be characterized as a mackinawite/ greigite mixture of nanocrystals.

Since most of the initially precipitated material was amorphous, we assume that a rearrangement into greigite without any restrictions on orientation is most likely. Presumably, the semi-ordered, layered features which probably contain octahedral iron could serve as seeds for greigite formation. However, the complete recrystallization of the sample is evident from the decrease in grain size from larger sheets into smaller greigite platelets (Figs. 3 and 7).

\subsubsection{Transformations of FeS upon heating}

The crystallinity of FeS slurries that were reacted at $120{ }^{\circ} \mathrm{C}$ for $2 \mathrm{~h}$ increased, as indicated by XRD patterns that were consistent with ordered mackinawite (Fig. 9). The mackinawite crystals formed after reaction at $120^{\circ} \mathrm{C}$ had platy habits (Fig. 10a) indicating some recrystallization of the sample. Both the formation of mackinawite with minor greigite at $120^{\circ} \mathrm{C}$, and the formation of hexagonal pyrrhotite at and above $150{ }^{\circ} \mathrm{C}$ are consistent with the results of similar quench experiments by Schoonen and Barnes (1991a). 


\subsubsection{Dry transformation of mackinawite into greigite}

The crystalline mackinawite almost completely converted to greigite after 3 months in the samples that were reacted at $120^{\circ} \mathrm{C}$ and then stored under anaerobic conditions (Table 3). The transition to greigite was thus much faster in a dry state compared to the solution-aged samples, suggesting that a different mechanism was active. Benning et al. (2000) and Rickard and Luther (2007) discussed that even a relatively small amount of oxygen, either on the surface of the original mackinawite or introduced when the sample is briefly handled in air, can be sufficient to trigger the conversion of mackinawite into greigite. Even though we tried to ensure fully anoxic conditions during sample storage, transfer and analyses, the complete exclusion of oxygen was probably not achieved and we believe that in our dry-stored samples the fast transition to greigite was caused by air exposure. Dry conversions of mackinawite to greigite were previously reported in controlled oxidation experiments (Lennie et al., 1997; Boursiquot et al., 2001), and also in magnetosomes from magnetotactic bacteria (Pósfai et al., 1998), where the transformation was attributed to uncontrolled oxidation by air during specimen handling. The transformation in the dry powder samples proceeded faster than in the solution-aged, ambient-temperature samples because the starting material was crystalline mackinawite instead of poorly ordered $\mathrm{FeS}_{\mathrm{am}}$, facilitating the solid-state conversion from mackinawite and greigite.

\section{Acknowledgments}

We thank László Merényi, Zoran Samardžija and Ilona Nyirő-Kósa for their help with the XRD, SEM and TEM measurements, respectively, István Dódony and János Lábár for discussions on FeS structures, and two anonymous reviewers for their helpful comments that significantly improved this manuscript. This study was supported by an intergovernmental Hungarian-Slovenian grant for research cooperation (TÉT-SI-10/ 2008) and an EU-Hungarian grant for research schools (TÁMOP-4.2.2./ B-10/1-2010-0025). A visit by Dorottya Csákberényi-Malasics to the Cohen Geochemistry Laboratory at Leeds was supported by the FIMIN project of the European Science Foundation. There the help of Sam Allshorn with laboratory training and the financial support from the School of Earth and Environment with access to facilities is acknowledged. JDRB and LGB acknowledge funding through the FP7 MINGRO Research and Training Network grant (MRTN-CT-2006-035488).

\section{References}

Benning, L.G., Wilkin, R.T., Barnes, H.L., 2000. Reaction pathways in the Fe-S system below $100{ }^{\circ} \mathrm{C}$. Chemical Geology $167,25-51$.

Berner, R.A., 1967. Thermodynamic stability of sedimentary iron sulfides. American Journal of Science 265, 773-785.

Boursiquot, S., Mullet, M., Abdelmoula, M., Génin, J.-M., Ehrhardt, J.-J., 2001. The dry oxidation of tetragonal $\mathrm{FeS}_{1-\mathrm{x}}$ mackinawite. Physics and Chemistry of Minerals 600-611.

Cahill, C.L., Benning, L.G., Barnes, H.L., Parise, J.B., 2000. In situ time-resolved X-ray diffraction of iron sulfides during hydrothermal pyrite growth. Chemical Geology 167, 53-63.

Chen, X., Zhang, X., Wan, J., Wang, Z., Qian, Y., 2005. Selective fabrication of metastable greigite $\left(\mathrm{Fe}_{3} \mathrm{~S}_{4}\right)$ nanocrystallites and magnetic properties through a simple solution-based route. Chemical Physics Letters 403, 396-399.

De Villiers, J.P.R., Liles, D.C., 2010. The crystal-structure and vacancy distribution in 6C pyrrhotite. American Mineralogist 95 (1), 148-152.

Devey, A.J., Grau-Crespo, R., de Leeuw, N.H., 2009. Combined density functional theory and interatomic potential study of the bulk and surface structures and properties of the iron sulfide mackinawite (FeS). Journal of Physical Chemistry C 112, 10,960-10,967.

Gallegos, T.J., Han, Y.-S., Hayes, K.F., 2008. Model predictions of realgar precipitation by reaction of As (III) with synthetic mackinawite under anoxic conditions. Environmental Science \& Technology 42, 9338-9343.

Gramp, J.P., Bigham, J.M., Jones, F.S., Tuovinen, O.H., 2010. Formation of Fe-sulfides in cultures of sulfate-reducing bacteria. Journal of Hazardous Materials 175, 1062-1067.

Harmandas, N.G., Koutsoukos, P.G., 1996. The formation of iron (II) sulfides in aqueous environments. Journal of Crystal Growth 167, 719-724.

Herbert Jr., R.B., Benner, S.G., Pratt, A.R., Blowes, D.W., 1998. Surface chemistry and morphology of poorly crystalline iron sulfides precipitated in media containing sulfate-reducing bacteria. Chemical Geology 144, 87-97.
Holmes, J., 1999. Fate of incorporated metals during mackinawite oxidation in sea water. Applied Geochemistry 14, 277-281.

Horiuchi, S., 1971. Zur Umwandlung von Mackinawit (FeS) in Greigit $\left(\mathrm{Fe}_{3} \mathrm{~S}_{4}\right)$ durch Elektronenstrahlen. Zeitschrift für Anorganische und Allgemeine Chemie 386, 208-212.

Horng, C.-S., Roberts, A.P., 2006. Authigenic or detrital origin of pyrrhotite in sediments? Resolving a paleomagnetic conundrum. Earth and Planetary Science Letters $241,750-762$.

Hunger, S., Benning, L.G., 2007. Greigite: a true intermediate on the polysulfide pathway to pyrite. Geochemical Transactions 8 (1), 1-20.

Jeong, H.Y., Lee, J.H., Hayes, K.F., 2008. Characterization of synthetic nanocrystalline mackinawite: crystal structure, particle size, and specific surface area. Geochimica et Cosmochimica Acta 72, 493-505.

Kornicker, W.A., 1988. Interactions of Divalent Cations with Pyrite and Mackinawite in Seawater and Sodium-chloride Solutions. Ph.D. Thesis. Texas A\&M University.

Lábár, J.L., 2005. Consistent indexing of a (set of) single crystal SAED pattern(s) with the ProcessDiffraction program. Ultramicroscopy 103, 237-249.

Larrasoana, J.C., Roberts, A.P., Musgrave, R.J., Grácia, E., Pinero, E., Vega, M., MartínezRuiz, F., 2007. Diagenetic formation of greigite and pyrrhotite in gas hydrate marine sedimentary systems. Earth and Planetary Science Letters 261, 350-366.

Lennie, A.R., Redfern, S.A.T., Schofield, P.F., Vaughan, D.J., 1995. Synthesis and Rietveld crystal structure refinement of mackinawite, tetragonal FeS. Mineralogical Magazine 59, 677-683.

Lennie, A.R., Redfern, S.A.T., Champness, P.E., Stoddart, C.P., Schofield, P.F., Vaughan, D.J. 1997. Transformation of mackinawite to greigite: an in situ X-ray powder diffraction and transmission electron microscope study. American Mineralogist 82, 302-309.

Liu, J., Valsaraj, K.T., Devai, I., DeLaune, R.D., 2008. Immobilization of aqueous $\mathrm{Hg}$ (II) by mackinawite (FeS). Journal of Hazardous Materials 157, 432-440.

Livens, F.R., Jones, M.J., Hynes, A.J., Charnock, J.M., Mosselmans, J.F.W., Hennig, C., Steele, H. Collison, D., Vaughan, D.J., Pattrick, R.A.D., Reed, W.A., Moyes, L.N., 2004. X-ray absorption specctroscopic studies of reactions of technetium, uranium and neptunium with mackinawite. Journal of Environmental Radioactivity 74, 211-219.

Michel, F.M., Antao, S.M., Chupas, P.J., Lee, P.L., Parise, J.B., Schoonen, M.A.A., 2005. Short- to medium range atomic order and crystallite size of the initial FeS precipitate from pair distribution function analysis. Chemistry of Materials 17, 6246-6255.

Mullet, M., Boursiquot, S., Abdelmoula, M., Génin, J.-M., Ehrhardt, J.-J., 2002. Surface chemistry and structural properties of mackinawite prepared by reaction of sulfide ions with metallic iron. Geochimica et Cosmochimica Acta 66, 829-836.

Mullet, M., Boursiquot, S., Ehrhardt, J.-J., 2004. Removal of hexavalent chromium from solutions by mackinawite, tetragonal FeS. Colloids and Surfaces 244, 77-85.

Ohfuji, H., Rickard, D., 2006. High resolution transmission electron microscopic study of synthetic nanocrystalline mackinawite. Earth and Planetary Science Letters 241, 227-233.

Pósfai, M., Dunin-Borkowski, R.E., 2006. Sulfides in biosystems. Reviews in Mineralogy and Geochemistry 61, 679-714.

Pósfai, M., Buseck, P.R., Bazylinski, D.A., Frankel, R.B., 1998. Iron sulfides from magnetotactic bacteria: structure, composition, and phase transitions. American Mineralogist 83, 1469-1481.

Renock, D., Gallegos, T., Utsunomiya, S., Hayes, K., Ewing, R.C., Becker, U., 2009. Chemical and structural characterization of As immobilization by nanoparticles of mackinawite $\left(\mathrm{FeS}_{\mathrm{m}}\right)$. Chemical Geology 268, 116-125.

Rickard, D., Luther III, G.W., 1997. Kinetics of pyrite formation by the $\mathrm{H}_{2} \mathrm{~S}$ oxidation of iron (II) monosulfide in aqueous solutions between 25 and $125^{\circ} \mathrm{C}$ : the mechanism. Geochimica et Cosmochimica Acta 61, 135-147.

Rickard, D., Luther, G.W., 2007. Chemistry of iron sulfides. Chemical Reviews 107, 514-562. Rickard, D., Morse, J.W., 2005. Acid volatile sulfide (AVS). Marine Chemistry 97, 141-197. Roberts, A.P., 1995. Magnetic properties of sedimentary greigite $\left(\mathrm{Fe}_{3} \mathrm{~S}_{4}\right)$. Earth and Planetary Science Letters 134, 227-236.

Schoonen, M.A.A., Barnes, H.L., 1991a. Mechanisms of pyrite and marcasite formation from solution: III. Hydrothermal processes. Geochimica et Cosmochimica Acta 55, 3491-3504

Schoonen, M.A.A., Barnes, H.L., 1991b. Reactions forming pyrite and marcasite from solution: II. Via FeS precursors below $100{ }^{\circ} \mathrm{C}$. Geochimica et Cosmochimica Acta 55, 1505-1514.

Shi, X., Sun, K., Balogh, L.P., Baker Jr., J.B., 2006. Synthesis, characterization, and manipulation of dendrimer-stabilized iron sulfide nanoparticles. Nanotechnology 17 , 4554-4560.

Skála, R., Císařová, I., Drábek, M., 2006. Inversion twinning in troilite. American Mineralogist 91 (5-6), 917-921.

Skinner, B.J., Erd, R.C., Grimaldi, F.S., 1964. Greigite, the thiospinel of iron; a new mineral. American Mineralogist 49, 543-555.

Taylor, P., Rummery, T.E., Owen, D.G., 1979. On the conversion of mackinawite and greigite. Journal of Inorganic and Nuclear Chemistry 41, 595-596.

Vaughan, D.J., Ridout, M.S., 1971. Mössbauer studies of some sulphide minerals. Journal of Inorganic and Nuclear Chemistry 33, 741-746.

Watson, J.H.P., Ellwood, D.C., Deng, Q., Mikhalowsky, S., Hayter, C.E., Evans, J., 1995 Heavy metal adsorption on bacterially produced FeS. Minerals Engineering 8 , 1097-1108.

Watson, J.H.P., Cressey, B.A., Roberts, A.P., Ellwood, D.C., Charnock, J.M., Soper, A.K. 2000. Structural and magnetic studies on heavy-metal-adsorbing iron sulphide nanoparticles produced by sulphate-reducing bacteria. Journal of Magnetism and Magnetic Materials 214, 13-30.

Wolthers, M., Van der Gaast, S., Rickard, D., 2003. The structure of disordered mackinawite. American Mineralogist 88, 2007-2015.

Wolthers, M., Charlet, L., van Der Weijden, C.H., van Der Linde, P.R., Rickard, D., 2005 Arsenic mobility in the ambient sulfidic environment: sorption of $\operatorname{arsenic}(\mathrm{V})$ and arsenic(III) onto disordered mackinawite. Geochimica et Cosmochimica Acta 69, 3483-3492. 